Bangladesh Journal of Neuroscience 2015; Vol. 31 (1): 15-20

\title{
A Study of Surgical Outcome of Supratentorial Meningioma
}

\author{
HARADHAN DEB NATH ${ }^{1}$, PROF. KANAK KANTI BARUA ${ }^{2}$, KAZI HAFIZ UDDIN ${ }^{3}$, PAWAN BHADUR \\ BHANDARI ${ }^{3}$, RANJIT KUMAR CHOWRASIA ${ }^{3}$, SHAHNEWAZ BARI ${ }^{3}$
}

\begin{abstract}
:
This was descriptive study. This study was carried out at the Department of Neurosurgery Bangabandhu Sheikh Mujib Medical University from April 2010 to April 2014. We have studied 35 cases. After collecting patients admission data, a brief history and clinical examination was done. Supratentorial meningioma was diagnosed primarily by contrast CT scan and MRI of brain which was confirmed by surgery \& histopathological examination. After surgery close follow up were done. Most of the sufferer were female $19(54 \%)$. The commonest age group was $40-59$ years $(37.14 \%)$. The commonest site of tumors were frontal convexity $8(22.9 \%)$ and the commonest histological types were meningotheliomatous 12 (34.3\%). All of the patients were undergone surgery. Majority of patients were improved after treatment 31(88.6\%).
\end{abstract}

Key words: Meningioma, craniotomy, intracranial pressure, Computerized Tomography scan, Magnetic Resonance Imaging

Introduction:

The term meningioma is the noncommittal all encompassing name coined by Harvey Cushing, for this tumor of the meninges which is usually benign ${ }^{1}$. Meningiomas account for $15 \%$ of intracranial tumors. They commonly occur in the fourth to sixth decades. Females have meningiomas more than males and this varies according to site from a ratio of 3:2 in the supratentorial area. Ninety per cent of meningiomas are intracranial and of these about $90 \%$ are supratentorial.

As with virtually all other brain tumors the etiology of menigiomas is unknown. Cases exist however in which the tumor has arisen under a fracture from an area of scarred dura or around a retained foreign body, ${ }^{2}$ conceivably these factors contributed to the formation of the mennigiomas but there is no definitive in meningioma formation especially during child hood ${ }^{3}$.

Neuro fibromatosis I and 2 ( NF-I and NF-2) genetic diseases inherited in autosomal dominant fashion may be associated with meningiomas.

The arachnoidal cap cells are most prevalent near collection as of arachonoid villi at the dural - venous sinuses and their large tributaries meningiomas may arise anywhere the cap cells are located ${ }^{4}$.

Meningiomas are well demarcated round or oval and frequently multilobulated. They are firm and pink and vary in consistency from soft and easily aspirable to rock hard 5 .

According to the site, the distribution meningioma are followers: convexity, parasaggittal, falx, olfactory groove, tuberculum Sella, sphenoid ridge, posterior fosa, intraventricular, intraorbital ${ }^{6}$.

\section{Methodology:}

This was a descriptive cross sectional study, which was carried out at the Department of neurosurgery BSMMU from April 2010 to April 2014. A total of 35 cases were selected before entry to the study and an informed written consent was taken from each patient. A structured questionnaire was made and data were collected. Diagnosis was confirmed by CT scan and MRI of brain and histopathological examination. The study was analysed by SPSS program.

\section{Results:}

A total of 35 patients were included in the Study (table I). Out of the female (54.60\%) outnumbered the male (table II). The age group of 40-59 years gripped the major proportion (34.14\%) of patients. Headache was the commonest $(71.4 \%)$ presenting symptoms followed by vomiting (34.38\%). Hemiparesis $(51.14 \%)$ was the presenting symptoms and followed by vomiting (34.38\%).

1. Associate Professor, Department of Neurosurgery, BSMMU, Dhaka.

2. Professor \& Chairman, Department of Neurosurgery, BSMMU, Dhaka.

3. Resident, Department of Neurosurgery, BSMMU, Dhaka. 
Hemiparesis (51.14\%) was the findings major proportion of patients (table III \& IV).

The commonest site of lesion (table $\mathrm{V}$ ) was frontal convexity (22.9\%). Meningotheliomatous (34.31\%) was the major varieties of lesion (table $\mathrm{VI}$ ). All of the patient were treated by surgery (table VII). Only eight patient develop different complication (table-VIII). After surgery about $88.6 \%$ improved, $8.6 \%$ deteriorated and one died (table IX).

Table-I

Distribution of the patients by age $(n=35)$

\begin{tabular}{lcc}
\hline Age & Number & Percentages $(\%)$ \\
\hline$>20$ & 05 & 14.3 \\
$20-39$ & 12 & 34.38 \\
$40-59$ & 13 & 37.14 \\
$<60$ & 05 & 14.3 \\
\hline Total & 35 & 100 \\
\hline
\end{tabular}

Table-II

Distribution of the patient by sex $(n=35)$

\begin{tabular}{lcc}
\hline Sex & Number & Percentages (\%) \\
\hline Male & 16 & 45.4 \\
Female & 19 & 54.6 \\
\hline Total & 35 & 100 \\
\hline
\end{tabular}

Table-III

Distribution of the patient by presenting symptoms

\begin{tabular}{lcc}
\hline Presenting Symptoms & Numbers & Percentages \\
\hline Headache & 25 & 71.4 \\
Vomiting & 12 & 34.38 \\
Convulsion & 12 & 34.35 \\
Altered Consciousness & 5 & 14.3 \\
Visual blurring & 5 & 14.3 \\
\hline
\end{tabular}

Table-IV

Distribution of patients by clinical findings

\begin{tabular}{lcc}
\hline Clinical Features & Numbers & Percentages \\
\hline Impaired higherPsychic & 12 & 34.38 \\
functions & & \\
Cranial nerve palsy & 7 & 20 \\
Hemi paresis & 18 & 51.14 \\
Mono paresis & 12 & 34.38 \\
\hline
\end{tabular}

Table-V

Distribution of patients by the site of lesions $(n=35)$

\begin{tabular}{|c|c|c|c|}
\hline Site & Numbers & \multicolumn{2}{|c|}{ Percentages } \\
\hline Frontal convexity & 8 & \multicolumn{2}{|r|}{22.9} \\
\hline Sphenoid wing & & \multicolumn{2}{|r|}{22.9} \\
\hline Fronto-Parietal convexity & & \multicolumn{2}{|r|}{17.1} \\
\hline Parietal convexity & & \multicolumn{2}{|r|}{14.3} \\
\hline Temporal & & \multicolumn{2}{|r|}{8.6} \\
\hline Olfactory groove & & \multicolumn{2}{|r|}{2.9} \\
\hline Falcine & & \multicolumn{2}{|r|}{5.7} \\
\hline Sellar & & \multicolumn{2}{|r|}{2.9} \\
\hline $\begin{array}{l}\text { Optic nerve sheath } \\
\text { meningioma }\end{array}$ & & \multicolumn{2}{|r|}{2.9} \\
\hline$\overline{\text { Total }}$ & 35 & \multicolumn{2}{|r|}{$100 \%$} \\
\hline \multicolumn{4}{|c|}{$\begin{array}{c}\text { Table-VI } \\
\text { Distribution of patients by histologicals types of } \\
\text { the tumor }(n=35)\end{array}$} \\
\hline Histological Types of the tumor & $\begin{array}{l}\text { Who } \\
\text { Grade }\end{array}$ & Number & Percentage \\
\hline leningotheliomatous & I & 12 & 34.3 \\
\hline rou & I & 8 & 22.9 \\
\hline Transi & i & 6 & 17.1 \\
\hline Psammomatous meningioma & i & 4 & 11.4 \\
\hline Angiomatous Atypical meningioma & a 1 & 2 & 5.7 \\
\hline Aty & I & 2 & 5.7 \\
\hline Anaplastic Meningioma & III & 1 & 2.9 \\
\hline
\end{tabular}

Table-VII

Distribution of patients by treatments options ( $n=35)$

\begin{tabular}{lcc}
\hline Treatment Option & Number & Percentages \\
\hline Surgery & 34 & 97.1 \\
Surgery+Gammaknife & 1 & 2.9 \\
surgery & & \\
\hline
\end{tabular}

Table-VIII

Distribution of patients by post operative complication $(n=35)$

\begin{tabular}{lcc}
\hline Complication & Number & Percentages \\
\hline Post operative haematoma & 3 & 8.6 \\
Seizure & 2 & 5.7 \\
Limb weakness & 1 & 2.9 \\
Cranial nerve palsy & 1 & 2.9 \\
Brain edema & 1 & 2.9 \\
\hline
\end{tabular}


Table-IX

Distribution of patients by outcome after treatment $(n=35)$

\begin{tabular}{lcc}
\hline Outcome & Number & Percentages \\
\hline Improved & 31 & 88.6 \\
Deteriorate & 3 & 8.6 \\
Death & 1 & 2.8 \\
\hline
\end{tabular}
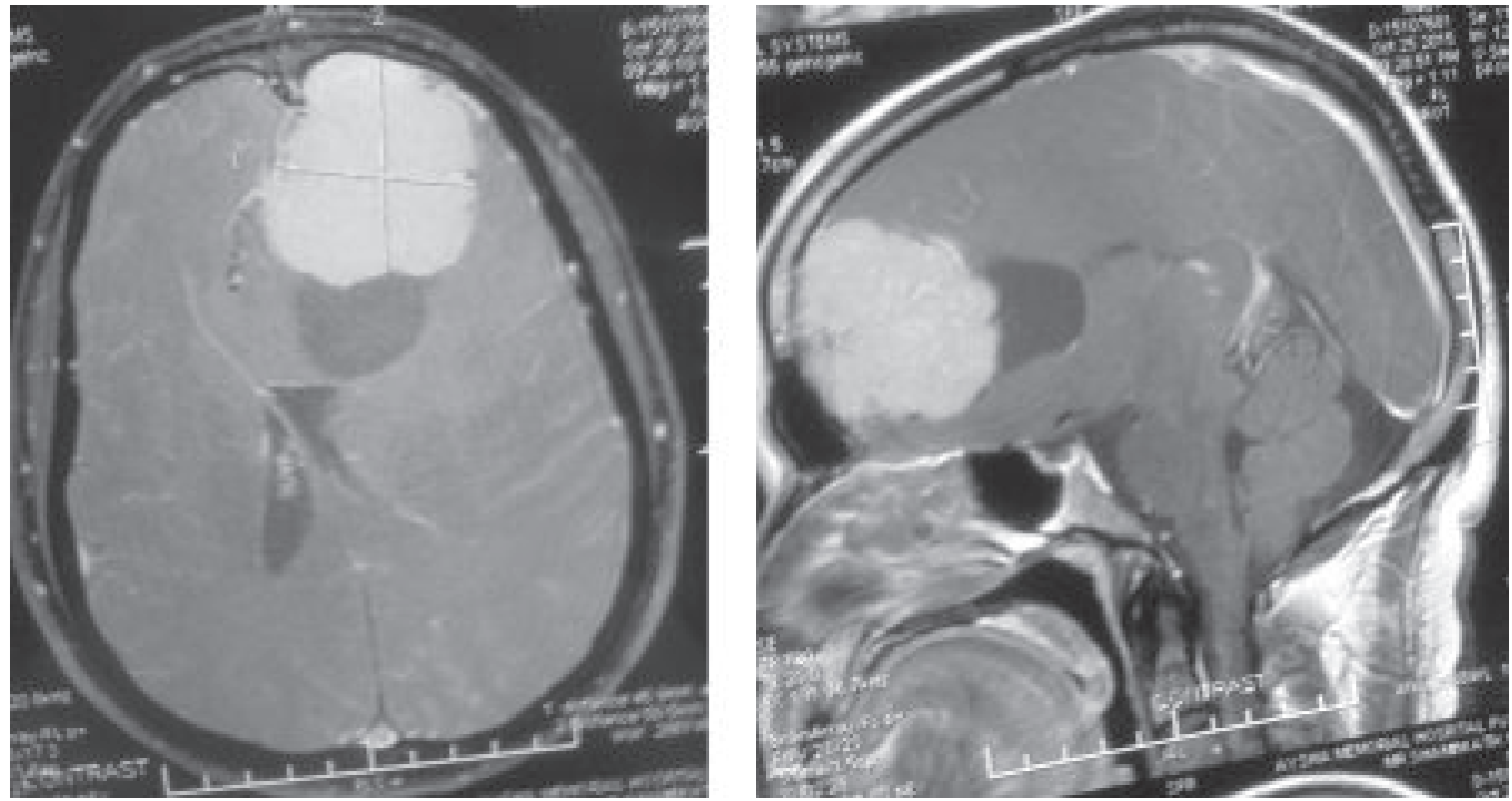

Fig. -1: Frontal falcine meningioma axial \& saggital section

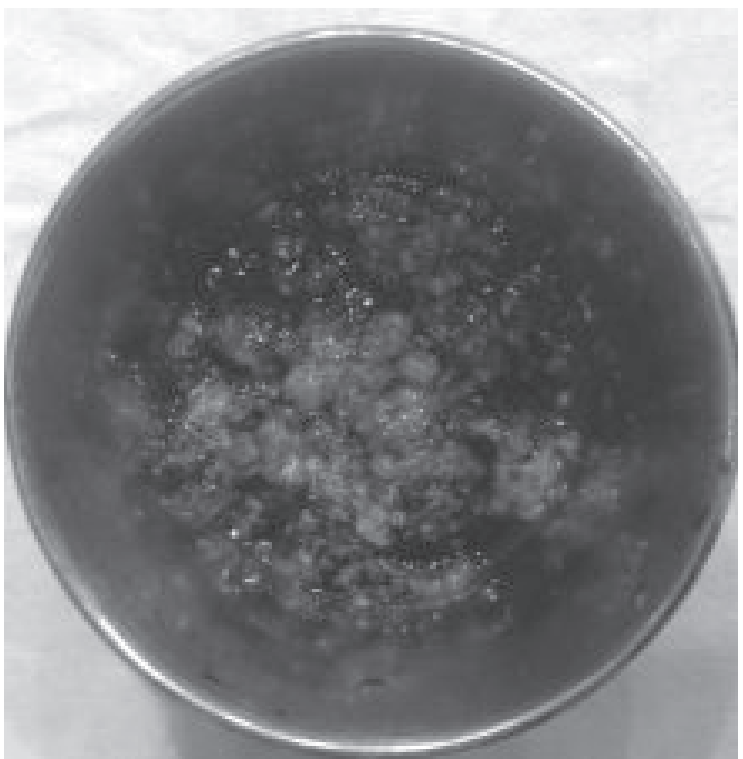

Fig. -2: Excise tumor

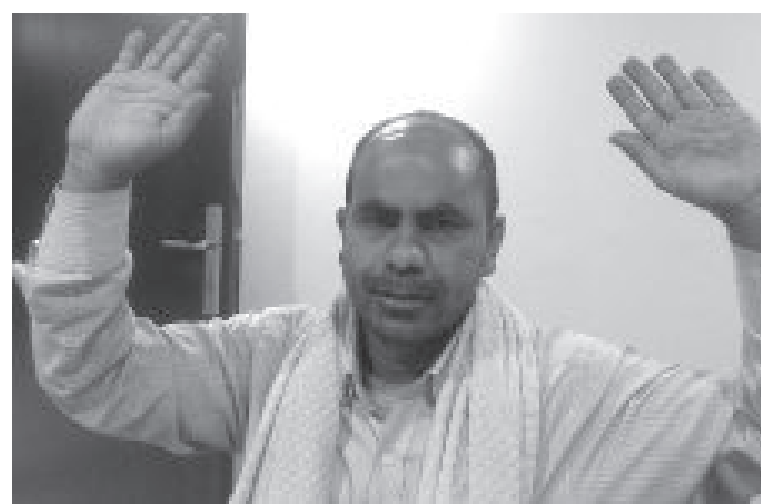

Fig. -3: Postoperative patient after three months 


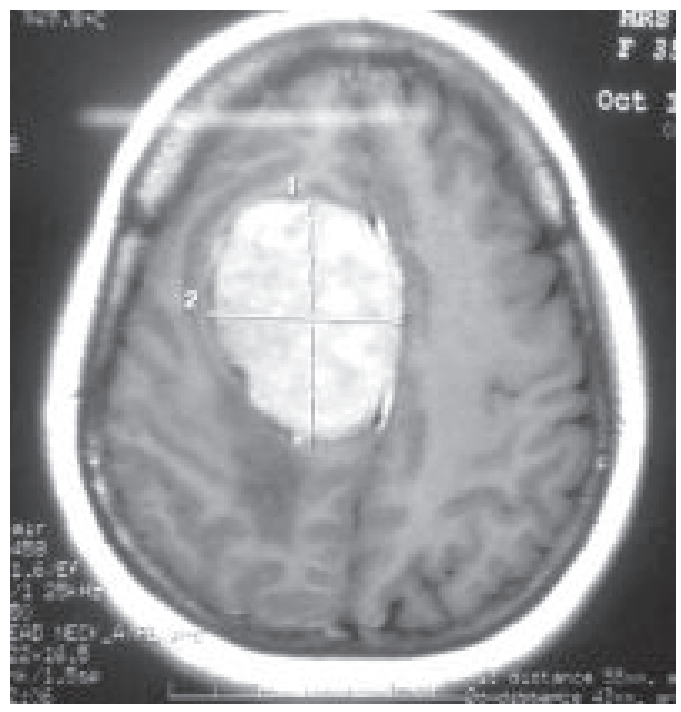

Fig. -4: Frontoparital convexcity \& paragittal meningioma

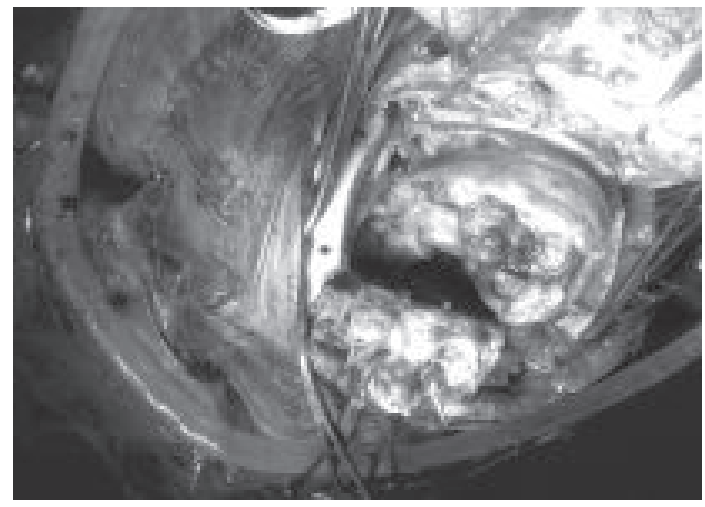

Fig. -5: Peroperative photograph

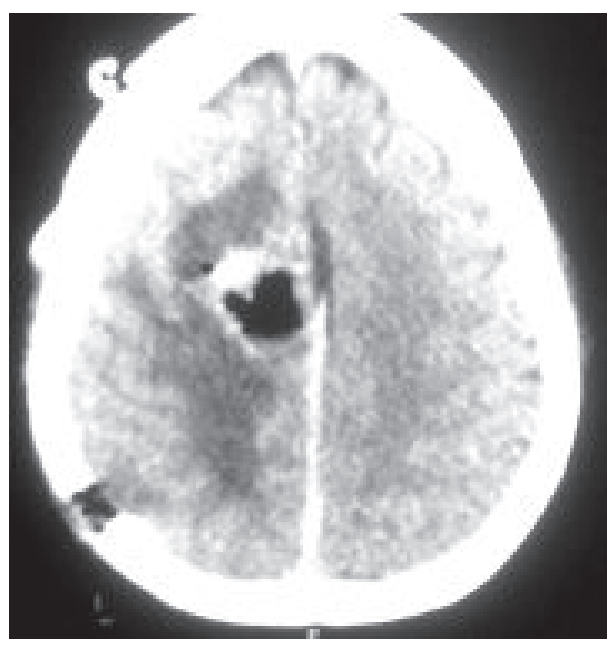

Fig. -6: Postoperative photograph

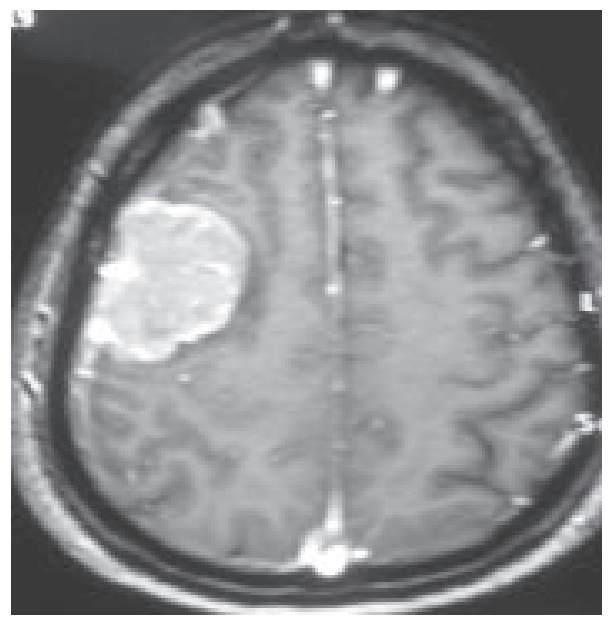

Fig. -7: Right frontoparietal meningioma

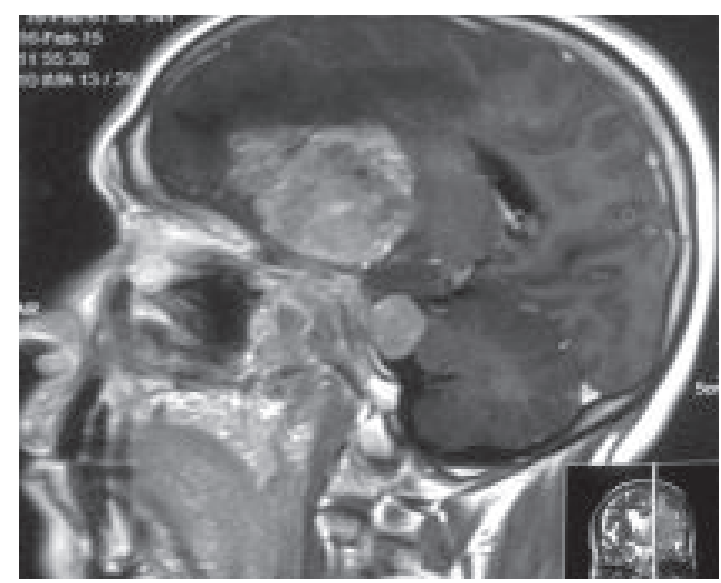

Fig.-8: Frontotemporal meningioma

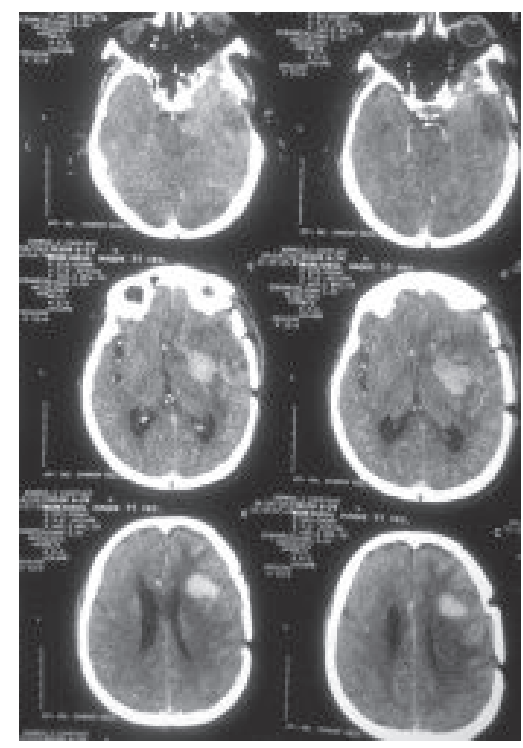

Fig.-9: Postoperative film with hematoma 


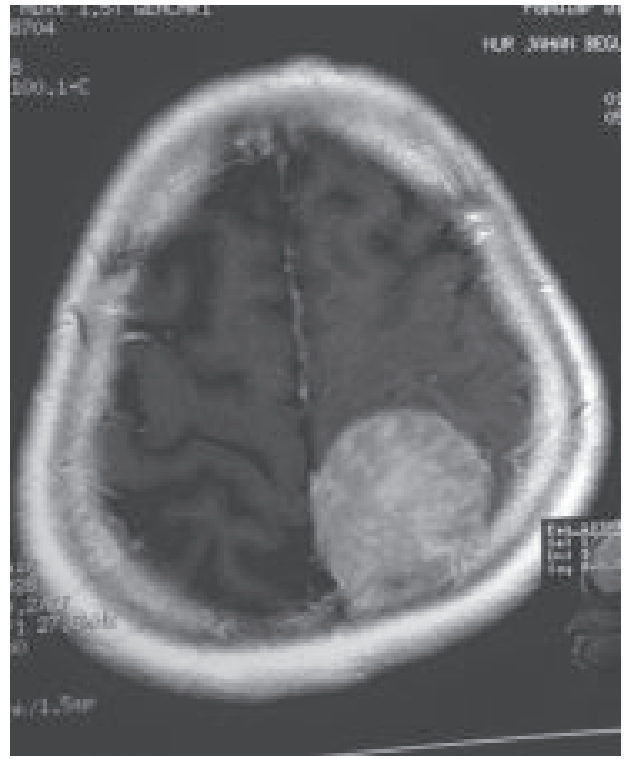

Fig.-10: Left parietal meningioma

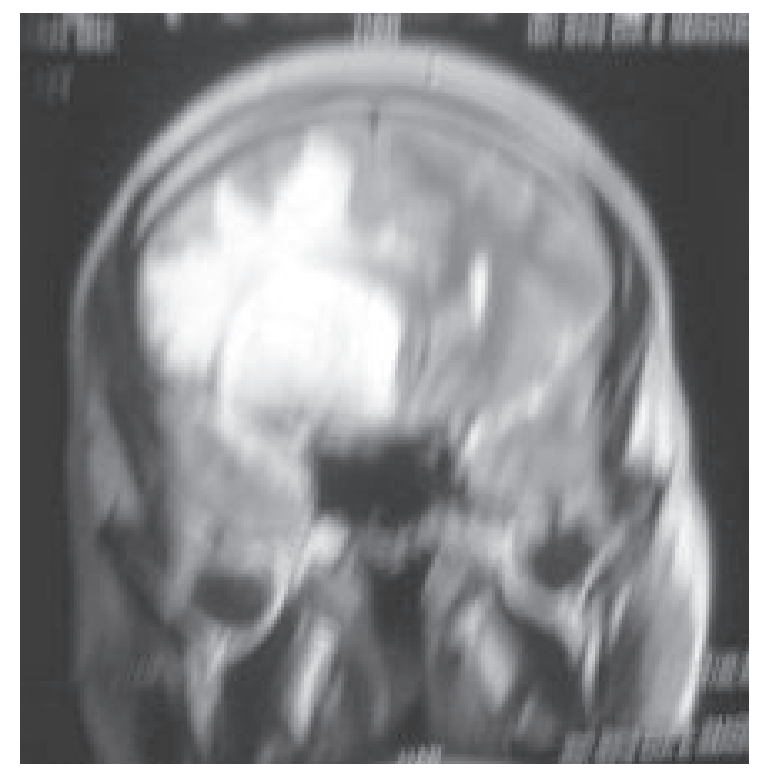

Fig.-11: Right sphenoid wing meningioma

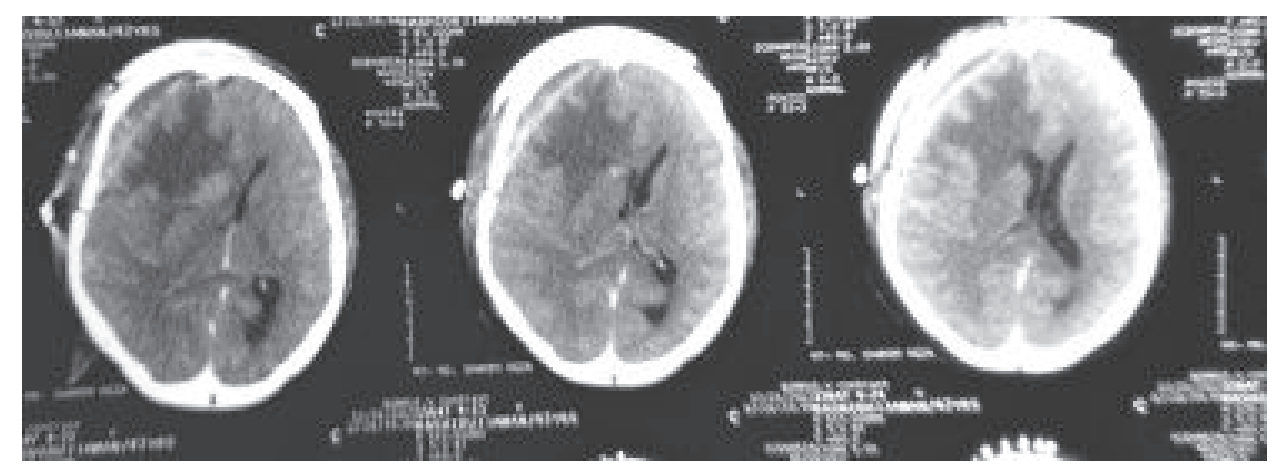

Fig.-12: Postoperative scan

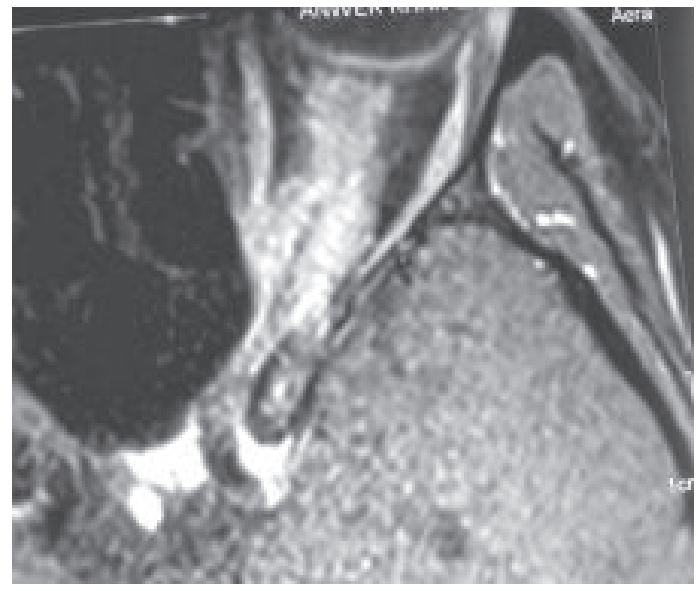

Fig.-13: Left optic nerve sheath meningioma

\section{Discussion:}

This was descriptive study which was carried out at the Department of Neurosurgery, BSMMU. The female \& male ratio of patients were 19:1 which was more or less concomitant with the study of Perry $\mathrm{A}^{7}$. The result of that study reveled female \& male ratio were 18:1

It was documented in a study the prevalence was more at $4^{\text {th }}$ to $6^{\text {th }}$ decade ${ }^{8}$.

In this study where the age group of 40-59 years were the major proportion of patients $(37.14 \%)$. The second highest proportion of age group were 20-39 years $(31.38 \%)$. 
In this series the commonest sites of tumors were frontal convexity meningioma i.e. frontal $\&$ anterior to the central sulcus.

In a study the majority of histological types were meningotheliomatous $08(32 \%)$. In previous study meningotheliomatous was the commonest type in this study $21(84 \%)$ patients improved after surgery, $8.4 \%$ patients remain same as before, $8.4 \%$ patients were detoriorated after surgery, previous study shows surgery was the treatment of choice in meningioma ${ }^{9}$.

In this study $(2.9 \%)$ only one patient was treated by radiotherapy + surgery in previous study $32 \%$ of patient was treated by partial resection with radiotherapy ${ }^{10}$.

\section{Conclusion:}

The present study was concluded that surgery is, the choice of treatment of meningiomia and further study is recommended.

\section{References:}

1. Cushing $\mathrm{H}$ Eisenhardt L. Meningiomas: their classification Regional Behavior Life History and surgical and end results speringfield, IL Charles C Thomas published;1938.

2. Al-Mefty $\mathrm{O}$ (ed). Meningiomas New York NY; Raven press ;1991.

3. Al-Mefty O, Kersh JE, Routh A, Smith RR. The long term side effects of radiation for benign brain tumors in adult. $\mathrm{J}$ Neurosurg 1990; 502-12.

4. Kida S, Yamashima T, Kubota T. All light and Immunohistochemical study of human arachnoid villi. J Neurosurg 1988;69 425-35.

5. Kleihues P, Cavene Wk (editors). World Health Organization Classification of Tumors: Pathology and Genetics of tumors of the nervous system. Lyon IARC Press 2000.

6. Zorludemiur S, Scheithuer BW, Hirose T. Clear cell meningioma: a clinicopathologic study of a potentially aggressive variant of meningioma. Am I Surg Pathol 1995;19:493-505.

7. Perry A, Scheithauer BW, Stafford SL. Rhabdoid meningioma an aggressive variant. Am I Surg Pathol 1998;2:1482-90.

8. Cource ME, Aker FV, Scheithauer BW. Chordiod meningioma; a clinicopatholgoic study of 42 cases. Am I Surge Pathol 2000 ;24 899-905.

9. Kondziolka D, Levy El, Niranjan A. Long term outcomes after meningiomas radiosurgery; physician and patient perspectives. J Neurosurg 1999; 91:44-50.

10. Barbaro N M, Gutin PH, Wilson CB. Radiation therapy in the treatment of partially resected meningiomas. J Neurosurg 1987;20:525-28. 